\title{
C-erbB-2 Expression and Codon 12 K-ras Mutations Both Predict Shortened Survival for Patients with Pulmonary Adenocarcinomas
}

\author{
Jeffrey A. Kern, " Robbert J. C. Slebos,, Bert Top, ${ }^{\ddagger}$ Sjoerd Rodenhuis, ${ }^{3}$ Donna Lager," Robert A. Robinson," David Weiner," \\ and David A. Schwartz* \\ Departments of * Internal Medicine and ${ }^{\ddagger}$ Pathology, University of Iowa, Iowa City, Iowa 52242; ${ }^{\S}$ Department of Pathology, The Johns \\ Hopkins University School of Medicine, Baltimore, Maryland 21205; $\$$ Division of Experimental Therapy and Clinical Oncology, The \\ Netherlands Cancer Institute, 1066 CX Amsterdam, The Netherlands; and "Department of Medicine, University of Pennsylvania, \\ Philadelphia, Pennsylvania 19104
}

\begin{abstract}
We evaluated the prognostic significance of p185c-erbB-2 expression and ras gene mutations in all patients diagnosed with a pulmonary adenocarcinoma between 1982 and 1985 at the University of Iowa. p185c-erbB-2 expression was detected in 15 cases (34\%). A ras gene mutation was found in 16 cases (36\%) and all were in codon-12 of $\mathrm{K}$-ras. No $\mathrm{N}$-ras mutations were identified. Both p185c-erbB-2 expression and a K-ras mutation were found only in codon-12 and present in six cases (14\%). By univariate analysis p185c-erbB-2 expression was associated with shortened survival $(P=0.02)$ while the presence of a K-ras mutation was not $(P=0.16)$. Multivariate analysis by the Cox proportional hazards model, controlling for patient age and tumor stage, also continued to identify p185c-erbB-2 expression as an independent unfavorable prognostic factor ( $P$ $=0.01$ ). In this model a K-ras mutation also approached significance as a poor prognostic indicator $(P=0.06)$. The impact of both p185c-erbB-2 expression and a K-ras mutation on survival was additive and highly significant $(P=0.004)$. This additive nature suggests that together these two markers identify a high-risk population of lung adenocarcinoma patients that may benefit from aggressive therapy. (J. Clin. Invest. 1994. 93:516-520.) Key words: c-erbB-2 • K-ras • lung cancer • lung adenocarcinoma
\end{abstract}

\section{Introduction}

The leading cause of cancer death in the United States for both men and women is lung cancer. In 1992, it was estimated that 93,000 men and 53,000 women died of this disease (1). Despite major advances in the treatment of many types of cancer over the past $25 \mathrm{yr}$, the 5 -yr survival of all patients with lung cancer has improved minimally, from 5 to $11 \%$ in blacks and 8 to $13 \%$ in whites (1). Even in stage I lung cancer, where tumor is localized to the lung and presents the best chance of cure, the long-term survival remains only $65 \%(2)$. Therefore, it appears that better techniques are needed for more accurate staging and identification of those patients at risk for disease relapse. Our

Address correspondence to Dr. Jeffrey A. Kern, Pulmonary Division, C-33A, GH, Department of Internal Medicine, University of Iowa School of Medicine, 200 Hawkins Drive, Iowa City, IA 52242.

Received for publication 6 July 1993 and in revised form 4 October 1993.

J. Clin. Invest.

(C) The American Society for Clinical Investigation, Inc.

$0021-9738 / 94 / 02 / 0516 / 05 \$ 2.00$

Volume 93, February 1994, 516-520 understanding of the molecular pathogenesis of lung cancer may now be at a point where novel strategies can be designed for this purpose. Preliminary data suggest that the identification of genetic or biochemical markers might allow physicians to predict a tumor's response to therapy or determine a patient's prognosis. Two markers that appear to have promise in this area are the presence of activating K-ras gene mutations and alterations in expression of the c-erbB-2 proto-oncogene.

Rodenhuis et al. first reported that a point mutation in codon 12 of the K-ras oncogene could be found in the tumors of approximately one third of all patients with pulmonary adenocarcinomas $(3,4)$. This relatively high prevalence of $\mathrm{K}$-ras activating mutations in lung adenocarcinomas has been independently confirmed by two laboratories $(5,6)$. Slebos et al. determined the clinical importance of this finding in patients treated surgically for cure, by showing that lung adenocarcinomas with activating $\mathrm{K}$-ras point mutations in comparison to mutation negative tumors tended to be smaller, less differentiated, and were predominantly stage I (7). More importantly, survival analysis showed that the presence of an activating $\mathrm{K}$ ras point mutation in the tumor was a strong and unfavorable prognostic factor, with a shortened duration of disease-free survival and an increased number of deaths due to progressive cancer (7). Even in patients with incurable disease treated palliatively, K-ras mutations continue to be a negative prognostic factor for overall survival (8).

The proto-oncogene c-erbB-2 has also been shown to be expressed in a relatively large portion of lung tumors and, importantly, also appears to be associated with poor survival. Weiner et al. first reported that the c-erbB-2 protein product, p185c-erbB-2, was expressed in $\sim 30 \%$ of human lung cancers (9). This observation has been independently confirmed by other laboratories (10-13). The clinical importance of p185cerbB-2 expression was studied by Kern et al., who found that expression of p185c-erbB-2 identified a subset of patients who had a poor prognosis with shortened survival (14). The association of p185c-erbB-2 expression with diminished 5-yr survival has been confirmed in an Asian population (11), (30\% for p $185 \mathrm{c}$-erbB-2 positive tumors vs. $52 \%$ for $\mathrm{p} 185 \mathrm{c}$-erbB- 2 negative tumors, $P<0.01$ ).

To date, the studies of $\mathrm{p} 185 \mathrm{c}-$ erbB-2 expression and K-ras mutations in lung cancer have focused on the impact of these single abnormalities on survival. However, malignant transformation is the result of multiple genetic and biochemical abnormalities (15), such as activation of proto-oncogenes ( 3,4 , $6-14,16-19)$, tumor suppressor gene inactivation $(18,20-$ 24 ), and chromosomal changes (25). Therefore, the effect of multiple biologic markers (26) on survival may be particularly important in stratifying patients into more precise prognostic categories (27). Given this line of reasoning, we have hypothe- 
sized that p185c-erbB-2 expression and K-ras gene mutations would both individually contribute prognostic information in patients with pulmonary adenocarcinomas. Furthermore, we have hypothesized that these two biologic markers would be interactive and the prognosis associated with the presence of both markers would be significantly worse than the sum of their individual contribution. Therefore, we retrospectively analyzed a series of resected lung cancers for p185c-erbB-2 expression and activating K-ras gene point mutations and performed an independent chart review to identify important clinical parameters and survival. Our data are the first to show the interactive nature and prognostic capabilities of these abnormalities; patients with pulmonary adenocarcinomas that express $\mathrm{p} 185 \mathrm{c}-\operatorname{erb\mathrm {B}-2}$ and harbor an activating $\mathrm{K}$-ras point mutation have a significantly shortened survival than patients whose tumor has none or only one of the markers. However, although these tumor markers independently contribute to survival, our results suggest that these tumor markers do not appear to interact in a multiplicative fashion.

\section{Methods}

Study population. We limited our study population to those individuals who underwent resection or open biopsy procedures at the University of Iowa Hospitals and Clinics between 1982 and 1985. This approach was chosen so that we could precisely stage the lung tumor based on operative findings and allow adequate clinical follow-up time. Adenocarcinomas were identified by morphological and immunohistochemical characteristics (28). Between 1982 and 1985, a total of 46 cases of pulmonary adenocarcinoma were resected or underwent an open biopsy procedure at the University of Iowa Hospitals and Clinics. 44 cases were studied; 2 cases had inadequate tissue specimens available for analysis and were not included. The p185c-erbB-2 expression status of 26 of these patients' adenocarcinomas has been previously reported (14). Survival data on these patients have been updated and included in this analysis. Various clinical parameters (14) were obtained through chart review by an independent reviewer unaware of the results of the laboratory analysis. The median follow-up time for all patients was $170 \mathrm{wk}$ ( range, 10-428 wk). Standard criteria as set forth by the International Staging System for Lung Cancer (2) were used to determine characteristics of the primary tumor, regional lymph nodes, metastases, and surgical stage.

Identification of p185c-erbB-2. DBW-2, a polyclonal anti-p185c$e r b \mathrm{~B}-2$ antiserum, was used. This antibody has been previously characterized $(9,14,29)$. Sections $(3-4 \mu \mathrm{m})$ were cut from paraffin-embedded, formalin-fixed tissue blocks, placed on pretreated (Probe-on; Fisher Scientific, Pittsburgh, PA) glass slides, dried at $37^{\circ} \mathrm{C}$ overnight followed by $60^{\circ} \mathrm{C}$ for $30 \mathrm{~min}$, and exposed to xylene for $5 \mathrm{~min}$ (three times). Tissues were rehydrated in decreasing concentrations of ethanol $(100,95$, and $70 \%)$ for $2 \mathrm{~min}$ ( twice), rinsed in distilled water, and endogenous peroxidase activity was blocked with $0.3 \%$ hydrogen peroxide in methanol ( $3 \mathrm{~min})$. Slides were washed in PBS ( $20 \mathrm{~min})$, excess liquid was blotted off, and non-immune goat serum (Vector Laboratories Inc., Burlingame, CA) was applied to reduce nonspecific background staining ( $20 \mathrm{~min})$. The serum was drained and rabbit p185cerbB-2 antiserum or a negative control applied $(60 \mathrm{~min})$. Slides were rinsed with PBS and drained, and a biotin-conjugated goat anti-rabbit antibody (Vector Laboratories) was added. After $30 \mathrm{~min}$, the slides were again rinsed with PBS, avidin was applied for $30 \mathrm{~min}$, the slides were rinsed in PBS, diaminobenzidine (Aldrich Chemical Co., Milwaukee, WI) was added ( $30 \mathrm{~min})$, and, again, the slides were rinsed with water and counterstained with Harris hematoxylin. After the counterstain, the tissue was dehydrated with increasing solutions of ethanol $(70,95$, and $100 \%$ ) for 2 min (twice) followed by clearing in xylene and mounting.

Positive controls of formalin-fixed, paraffin-embedded human lung were used with each staining reaction. Negative controls consisted of tissue sections from the paraffin-embedded lung cancer block to be studied for p185c-erbB-2 expression treated with an irrelevant antibody (rabbit anti-mouse IgG; Vector Laboratories). All microscopic analyses were performed by the same pathologist (R. A. Robinson). A tissue specimen exhibiting membrane, or membrane and cytoplasmic reactivity with DBW-2 antiserum, throughout the tissue section was considered positive. No reactivity or cytoplasmic reactivity without membrane localization was considered negative.

$D N A$ Isolation and amplification of ras-specific sequences by PCR. This procedure has been previously published $(30,31)$. A 5- $\mu \mathrm{m}$ section was cut from each tissue block and collected in an Eppendorf reaction tube. $300 \mu$ l of lysis buffer was added ( $10 \mathrm{mM}$ Tris $\mathrm{HCl}, \mathrm{pH} 8.0,50 \mathrm{mM}$ $\mathrm{KCl}, 2.5 \mathrm{mM} \mathrm{MgCl}_{2}, 0.01 \%$ (wt/vol) gelatin, $0.5 \%$ Tween 80 , and 0.1 $\mathrm{mg} / \mathrm{ml}$ of proteinase $\mathrm{K}$ ). The samples were incubated for $18-24 \mathrm{~h}$ at $37^{\circ} \mathrm{C}$ and then centrifuged for $10 \mathrm{~min}$ at $12,000 \mathrm{rpm}$. The supernatant was pipetted into a new tube, and used for amplification.

PCR amplification was done in a 50-70 $\mu$ l reaction volume using 1 $\mu \mathrm{l}$ of DNA sample, with the following final concentrations: $70 \mathrm{mM}$ Tris $\mathrm{HCl}\left(\mathrm{pH} 8.8\right.$ at $\left.25^{\circ} \mathrm{C}\right), 15 \mathrm{mM}\left(\mathrm{NH}_{4}\right)_{2} \mathrm{SO}_{4}, 3 \mathrm{mM} \mathrm{MgCl} 2,10 \mathrm{mM}$ $\beta$-mercaptoethanol, $100 \mu \mathrm{M}$ of each dNTP, $0.5 \mu \mathrm{M}$ of each amplimer, and $200 \mathrm{U} / \mathrm{ml}$ of Taq polymerase (Perkin-Elmer Cetus, Emeryville, CA). Two different sets of amplimers were used to amplify the K-ras oncogene, each set amplifying different regions around codon 12 ( set 1: 5'-GGCCTGCTGAAAATGACTGA-3', and 5'-TGATTCTGAATTAGCTGTAT-3'; set 2: 5'-GACTGAATATAAACTTGTGG-3' and 5'CTATTGTTGGATCATATTCG3'). $25 \mu$ l of sterile water with a drop of paraffin oil was added to the DNA samples, and the tubes were incubated at $100^{\circ} \mathrm{C}$ for $10 \mathrm{~min}$ to inactivate the proteinase $\mathrm{K}$ and denature the DNA. Then $25 \mu$ lof the $2 \times$ amplification mixture was added, and the amplification reaction started. Amplification was done for 35 cycles at the following temperatures: $94^{\circ} \mathrm{C}$ for $30 \mathrm{~s}, 54^{\circ} \mathrm{C}$ for $30 \mathrm{~s}$, and $72^{\circ} \mathrm{C}$ for $60 \mathrm{~s}$ in a Dri-block device (Techne Corp., Cambridge, UK). After amplification, the paraffin oil overlay was removed by adding $150 \mu \mathrm{l}$ of ether to each tube, and mixing. The two phases were allowed to separate and the top layer containing the paraffin oil/ether was removed.

Detection of the point mutations by oligodeoxynucleotide hybridization. Hybridization membranes ( Nytran-N, Schleicher \& Schuell, Dassel, Germany) were pretreated with $10 \times$ SSC $(1 \times$ SSC is $150 \mathrm{mM}$ $\mathrm{NaCl}, 15 \mathrm{mM} \mathrm{Na}$ citrate at $\mathrm{pH} 7.6$ ) and dried. For each oligodeoxynucleotide probe, one membrane was cut and attached to a glass plate. PCR samples were then sequentially denatured by incubation at $100^{\circ} \mathrm{C}$ for 1-2 min, and 1- $\mu$ l portions were dotted on to the membranes. The membranes were dried and the DNA cross-linked by exposure to ultraviolet irradiation for $2 \mathrm{~min}$. Each membrane was separately hybridized in a minimal volume of hybridization solution ( $3 \mathrm{M}$ tetramethylammonium chloride, $50 \mathrm{mM}$ Tris $\mathrm{HCl}, \mathrm{pH} 7.5,5 \mathrm{mM}$ ethylenediaminetetraacetate, $1 \%$ SDS and $1 \%(\mathrm{wt} / \mathrm{vol})$ milk protein [Protifar, Nutricia, The Netherlands]). Radioactive oligodeoxynucleotide probes were prepared for every possible point mutation in the ras gene to be investigated. Exact nucleotide sequences of these probes have been described previously $(30,31)$. Labeling reactions contained 5 pmol of oligodeoxynucleotide (33 ng of a 20 -mer), $10 \mu \mathrm{Ci}$ (3.3 pmol) of $\alpha\left[{ }^{32} \mathrm{P}\right]$ ATP (Amersham Inc., Amersham, UK), $50 \mathrm{mM}$ Tris $\mathrm{HCl}, \mathrm{pH} 7.5,8 \mathrm{mM}$ $\mathrm{MgCl}_{2}, 5 \mathrm{mM} \beta$-mercaptoethanol, $200 \mathrm{U} / \mathrm{ml}$ of T4 polynucleotide kinase (Boehringer Mannheim, Mannheim, Germany), in a 5- $\mu$ l reaction volume. Incubation was done for $30 \mathrm{~min}$ at $37^{\circ} \mathrm{C}$, and the labeled oligodeoxynucleotide separated from the nonincorporated nucleotides by spindialysis. Hybridization was performed with $0.1 \mathrm{pmol}(\sim 0.5 \mathrm{ng}$ of a 20-mer) of labeled oligodeoxynucleotide for every $10 \mathrm{~cm}^{2}$ membrane for at least $1 \mathrm{~h}$ at $56^{\circ} \mathrm{C}$. The membranes were then washed at $63^{\circ} \mathrm{C}$ in $5 \times$ SSPE $\left(1 \times\right.$ SSPE is $180 \mathrm{mM} \mathrm{NaH}_{2} \mathrm{PO}_{4}, 1 \mathrm{mM}$ EDTA $)$ and $0.1 \%$ SDS for $20 \mathrm{~min}$, and subsequently with $2 \times \mathrm{SSC}$ at room temperature to remove the remaining SDS. Perfectly hybridizing oligodeoxynucleotide sequences are retained on the membranes, and were detectable by autoradiography at $-70^{\circ} \mathrm{C}$.

Statistical analysis. The relationship between the cumulative probability of survival and a variety of clinical variables, including the ex- 
pression of p185c-erbB-2 and K-ras mutations, was determined by using the log rank test, as described by Kaplan and Meier (32). Censoring was performed for subjects who were either lost to follow-up or were followed for less time than the longest survivor. The clinical factors that were significantly associated with the cumulative probability of survival were tested in a hierarchical multivariate survival analysis, as described by Cox and Oakes (33). All interactions were tested among clinical factors that were found to be independently associated with survival.

\section{Results}

Prevalence of c-erbB-2 expression and codon $12 \mathrm{~K}$-ras mutations in human lung cancer. We chose to analyze only pulmonary adenocarcinomas, as previous analyses of squamous cell lung cancer did not identify a high prevalence of K-ras mutations or clinical importance of p185c-erbB-2 expression $(3,4$, $7,9,14)$. Our study population consisted of patients with relatively early stages of lung cancer who averaged $62 \mathrm{yr}$ of age (Table I). Interestingly, $68 \%$ of our patients died of progressive lung cancer, with their median survival being of $24 \mathrm{wk}$. Among our patients with adenocarcinoma of the lung, p185c-erbB-2 was expressed in 15 of the 44 samples analyzed (34\%), and K-ras activating point mutations were present in 16 tumors $(36 \%)$, as noted in Table I. All point mutations were found in $\mathrm{K}$-ras codon 12, with no mutations found in K-ras codon 13, 61 , or N-ras. The predominant point mutation was a G-T transversion in position 1 of codon 12 (glycine [GGT] $\rightarrow$ cysteine [TGT]; 10 of $16,62.5 \%$ ), with a G-T transversion in position 2 occurring in $12.5 \%$ of the cases (glycine [GGT] $\rightarrow$ valine [GTT]; 2 of 16) and a G-A transition in position 2 in $25 \%$ of the cases (glycine [GGT] $\rightarrow$ aspartic acid [GAT]; 4 of 16). 9 of 15 tumors with abnormal p185c-erbB-2 expression had a wild type K-ras gene. 10 of 16 tumors with an activating point mutation in the K-ras gene did not express p $185 \mathrm{c}$-erbB2. Six carcinomas expressed p185c-erbB-2 and harbored an activated K-ras gene.

Table I. Characteristics of Study Population

\begin{tabular}{|c|c|c|}
\hline Variables & $(n=44)$ & \\
\hline \multicolumn{3}{|l|}{ Categorical } \\
\hline Sex Male & 20 & \\
\hline Stage I & 23 & \\
\hline II & 8 & \\
\hline $\mathrm{III}_{\mathbf{A}}$ & 5 & \\
\hline $\mathrm{III}_{\mathbf{B}}$ & 0 & \\
\hline IV & 8 & \\
\hline Smoker & 39 & \\
\hline p185c-erbB-2 expression & 15 & \\
\hline K-ras mutation & 16 & \\
\hline \multicolumn{3}{|l|}{ Both } \\
\hline \multicolumn{3}{|l|}{ p185c-erbB-2 expression } \\
\hline and $\mathrm{K}$-ras mutation & 6 & \\
\hline Died & 30 & \\
\hline \multicolumn{3}{|l|}{ Continuous } \\
\hline Tumor size & $3.64 \pm 2.26 \mathrm{~cm}^{*}$ & $1-10^{\ddagger}$ \\
\hline Pack years & $48.1 \pm 27.5 \mathrm{yr}$ & $0-100$ \\
\hline Age & $61.5 \pm 9.5 \mathrm{yr}$ & $35-78$ \\
\hline Survival & $25.73 \pm 18.33 \mathrm{wk}$ & $1-61$ \\
\hline
\end{tabular}

${ }^{*}$ Mean \pm SD. ${ }^{\ddagger}$ Range.
Univariate analyses were performed using the Cox proportional hazard method. As shown in Table II, numerous patient and tumor characteristics significantly increased a patient's risk of early death. As expected, many important clinical characteristics, including weight loss, tumor size, the presence of metastases, and surgical stage, were related to the probability of survival in patients with adenocarcinoma. p185c-erbB-2 expression was associated with a 2.4-fold increase in the patient's relative risk of dying as compared to those tumors that did not express p185c-erbB-2 $(P=0.02)$. The presence of any codon $12 \mathrm{~K}$-ras point mutation carried a 1.7 -fold increased risk of dying that did not reach statistical significance $(P=0.16)$. Specific K-ras point mutations were also examined to determine if any individual mutation carried a worse prognosis than the mutations considered as a group. The $\mathrm{G}$ to $\mathrm{A}$ transition was associated with a slightly higher hazard ratio $(2.8,95 \%$ confidence interval $0.8,9.9)$ that also did not achieve statistical significance $(P=0.10)$.

Multivariate analyses were performed to determine the independent contribution of p185c-erbB-2 expression and K-ras mutations in patients with adenocarcinoma of the lung, after controlling for other factors known to affect survival. Multivariate models were developed to test all the clinical variables, specifically examining the relationship between p185c-erbB-2 expression, K-ras mutation, and survival. Surprisingly, variables beyond p185c-erbB-2 expression, K-ras mutation, age, and tumor stage failed to significantly contribute to the overall fit of the model. Two models were found to best represent the data (Table III). In model I, when controlling for patient age and tumor stage, both p185c-erbB-2 expression and the presence of an activating K-ras mutation were associated with survival. Although the presence of a K-ras point mutation was associated with an excess risk of dying ( hazard ratio $=2.1$ ), this association did not achieve statistical significance in a twotailed test with the $95 \%$ confidence interval still including 1 . In model II, we examined the multiplicative effect on survival of both abnormalities present in a single carcinoma (Table III). The combination of both factors in a single tumor had an additive effect resulting in a profound impact on patient survival, with a hazard ratio of 4.4 (95\% confidence interval 1.6, 12.3, $P$ $=0.004)$. The individual and combined impact of p185cerbB-2 and K-ras on survival is further illustrated in Fig. 1. Kaplan-Meier survival curves suggest that patients with either p185c-erbB-2 expression or a K-ras point mutation have a

Table II. Cox Proportional Hazards Analysis of Various Prognostic Factors in Patients with Lung Adenocarcinoma

\begin{tabular}{lccc}
\hline \multicolumn{1}{c}{ Characteristic } & $\begin{array}{c}\text { Hazard } \\
\text { ratio }\end{array}$ & $\begin{array}{c}95 \% \text { Confidence } \\
\text { interval }\end{array}$ & $P$ \\
\hline Weight loss & 6.0 & $(1.3,27.4)$ & 0.02 \\
Pack years & 1.0 & $(1.0,1.0)$ & 0.52 \\
$\mathrm{~T}^{*}$ & 2.3 & $(1.1,4.8)$ & 0.03 \\
Metastasis & 6.0 & $(2.9,15.0)$ & 0.0001 \\
Stage & 1.7 & $(1.2,2.3)$ & 0.002 \\
Age & 1.0 & $(1.0,1.1)$ & 0.17 \\
Tumor size & 1.3 & $(1.1,1.6)$ & 0.001 \\
p185c-erbB-2 expression & 2.4 & $(1.2,4.9)$ & 0.02 \\
K-ras mutation & 1.7 & $(0.8,3.5)$ & 0.16 \\
& & & \\
\hline
\end{tabular}

* T1 - T4 as defined by Mountain (2). 
Table III. Cox Proportional Hazards Model for Factors Associated with Survival of Adenocarcinoma Patients

\begin{tabular}{lccc}
\hline & $\begin{array}{c}\text { Hazard } \\
\text { ratio }\end{array}$ & $\begin{array}{c}95 \% \text { Confidence } \\
\text { interval }\end{array}$ & \multicolumn{1}{c}{$P$} \\
\hline Model I & & & \\
$\quad$ K-ras mutation & 2.1 & $(1.0,4.4)$ & 0.06 \\
p185c-erbB-2 expression & 2.6 & $(1.2,3.5)$ & 0.01 \\
Stage & 1.9 & $(1.4,2.7)$ & 0.0001 \\
Age & 1.0 & $(1.0,1.1)$ & 0.06 \\
Model II & & & \\
p185c-erbB-2 expression & & & \\
$\quad$ and K-ras mutation & 4.4 & $(1.6,12.3)$ & 0.004 \\
Stage & 2.1 & $(1.3,3.0)$ & 0.0001 \\
Age & 1.1 & $(1.0,1.1)$ & 0.03 \\
& & & \\
\hline
\end{tabular}

shorter survival. Those patients whose tumors have both abnormalities have a significantly shortened survival when compared to all other subjects with adenocarcinoma of the lung.

\section{Discussion}

This work is the first analysis in lung cancer of the interaction of two known prognostic markers, c-erbB-2 expression and ras gene mutation, attempting to stratify patients into more accurate prognostic groups. Our results demonstrate that tumor stage was the single most important prognostic factor in patients with adenocarcinoma of the lung. However, after controlling for the stage of the tumor, p185c-erbB-2 expression was significantly related to diminished survival and the K-ras point mutation tended to be associated with diminished survival. More importantly, the combination of these two factors on survival identifies a population with a poorer prognosis when compared to all other subjects with adenocarcinoma of the lung. The poorer survival of these patients whose tumors had both abnormalities than of those patients who had only one abnormality reinforces the independent effect of these biologic tumor markers on survival. Our results further indicate that these independent prognosticators do not appear to interact biologically.

The role of p185c-erbB-2 and K-ras mutations in pulmonary tumorigenesis remains unclear. Both abnormalities have been found in roughly one third of all pulmonary adenocarcinomas examined; and, as shown in this study, the abnormalities overlap, with both being present in $14 \%$ of cases. Their role, if any, in the transformation of normal pulmonary epithelium in vivo is not known. Regardless of their role in tumorigenesis, they clearly serve an important function as prognostic markers and potential guides for therapy.

The prevalence of $\mathrm{p} 185 \mathrm{c}$-erbB-2 expression or a K-ras mutation in our study population agrees with other studies that have examined these markers. In addition, the effect of p185cerbB-2 expression on survival is also supported by our previous study and that of Tateishi et al. $(12,14)$. However, our results suggest that $\mathrm{K}$-ras mutations did not play as significant a role in predicting survival in our patient population, as has been suggested by Slebos et al. (7) or Mitsudomi et al. (8). These investigators observed that K-ras was significantly associated with survival in patients with adenocarcinoma of the lung. Although our results suggest a trend toward significance, we did not find K-ras to be statistically associated with survival. There are important differences in the patient populations of these three studies that most likely account for this discrepancy. Slebos et al. studied stage I, II, and IIIa patients treated with curative intent by complete surgical resection. Our study involved all patients diagnosed with adenocarcinoma of the lung during the study period, regardless of treatment intent, and included patients with stage IV tumors. Mitsudomi et al. studied a broader range of histologic tumor type than this study, including nonadenocarcinomas, which represented $42 \%$ of the K-ras mutations. Furthermore, only $58 \%$ of the mutations found were at codon 12 of K-ras, while all of the mutations in our

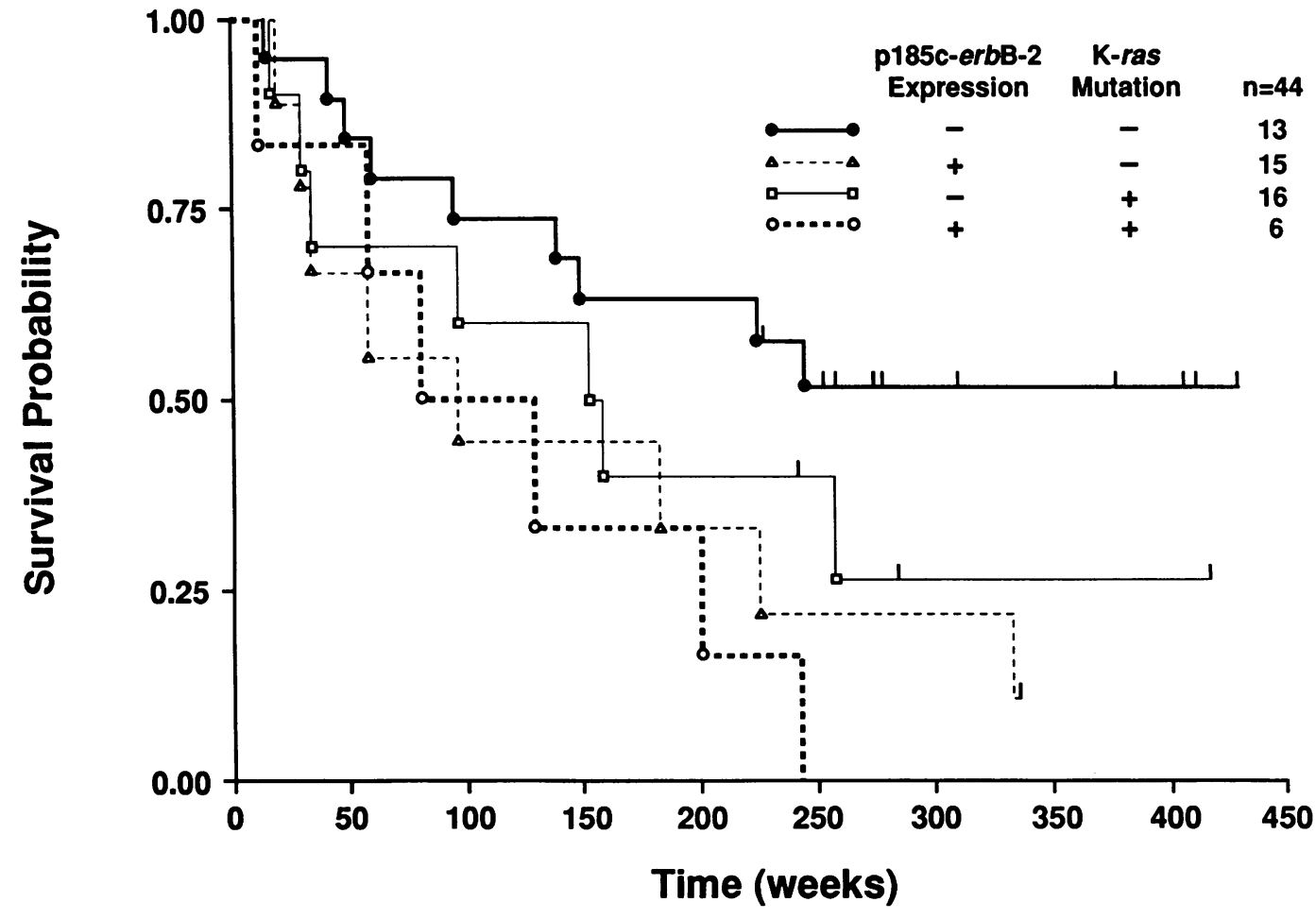

Figure 1. Actuarial curve for survival of all patients with lung adenocarcinoma according to p185c-erbB-2 expression, $\mathrm{K}$-ras codon 12-point mutation, and combinations. The Kaplan-Meier method was used to estimate the survival distribution for each subgroup. The log rank sum test was used to statistically compare the survival curves. 
population were at codon 12 . In addition, they had to be able to establish a cell line from the tumor to be included in the analysis, which in itself may prove to be a poor prognostic indicator.

Our multivariate models suggest that the expression of cerbB-2 and K-ras mutations independently contributes to survival in patients with adenocarcinoma of the lung. However, these two prognostic factors appear to function in parallel and do not interact biologically, since the impact of both factors on survival is additive, not multiplicative. This would suggest that these two factors have independent contributions to the invasive and metastatic qualities of adenocarcinoma of the lung. Identifying the tumor biology inherent in these prognostic biomarkers may provide new avenues for directed and combined therapeutic interventions.

The presence of a K-ras point mutation or c-erbB-2 expression may be of more value than just as a prognostic marker. Recent reports suggest that tumors that acquire a K-ras point mutation in vitro may become resistant to radiation and to several drugs, including cisplatin $(34,35)$. Whether this effect is relevant to patients with lung cancer is not clear. However, the poorer survival of those patients with both abnormalities suggests that these biological markers may independently contribute to drug resistance.

Our results indicate that further studies are needed to evaluate the clinical and biological importance of tumors expressing p185c-erbB-2 and K-ras point mutations. In particular, the relation to specific therapeutic interventions may allow us to extend survival in this high-risk population of patients with adenocarcinoma of the lung.

\section{Acknowledgments}

The authors wish to acknowledge Siegina Evers and Scott Van Fossen for expert technical assistance and Sandy Cosgrove for secretarial assistance.

\section{References}

1. Boring, C. C., T. S. Squires, and T. Tong. 1993. Cancer Statistics, 1993. CA - Cancer J. Clin.. 43:7-26.

2. Mountain, C. F. 1986. A new international staging system for lung cancer. Chest. 89(Suppl.):225S-233S.

3. Rodenhuis, S., R. J. C. Slebos, A. J. M. Boot, S. G. Evers, W. J. Mooi, S. S. Wagenaar, P. C. van Bodegom, and J. L. Bos. 1988. Incidence and possible clinical significance of K-ras oncogene activation in adenocarcinoma of the human lung. Cancer Res. 48:5738-5741.

4. Rodenhuis, S., M. L. van de Wetering, W. J. Mooi, S. G. Evers, N. van Zandwijk, and J. L. Bos. 1987. Mutational activation of the K-ras oncogene. $N$. Engl. J. Med. 317:929-935.

5. Suzuki, Y., M. Orita, M. Shiraishi, K. Jayashi, and T. Sekiya. 1990. Detection of ras gene mutations in human lung cancers by single-strand conformation polymorphism analysis of polymerase chain reaction products. Oncogene. 5:1037-1043.

6. Mitsudomi, T., J. Viallet, J. L. Mulshine, R. I. Linnoila, J. D. Minna, and A. F. Gazdar. 1991. Mutations of ras genes distinguish a subset of non-small-cell lung cancer cell lines from small-cell lung cancer cell lines. Oncogene. 6:13531362 .

7. Slebos, R. J. C., R. E. Kibbelaar, O. Dalesio, A. Kooistra, J. Stam, C. J. L. M. Meijer, S. S. Wagenaar, R. G. J. R. A. Vanderschueren, N. van Zandwijk, W. J. Mooi, J. L. Bos, and S. Rodenhuis. 1990. K-ras oncogene activation as a prognostic marker in adenocarcinoma of the lung. $N$. Engl. J. Med. 561-565.

8. Mitsudomi, T., H. Koie, J. L. Mulshine, R. Phelps, J. Viallet, H. Pass, J. D. Minna, and A. F. Gazdar. 1991. ras gene mutations in non-small cell lung cancers are associated with shortened survival irrespective of treatment intent. Cancer Res. 51:4999-5002.

9. Weiner, D. B., J. Nordberg, R. Robinson, P. C. Nowell, A. Gazdar, M. I. Green, W. V. Williams, J. A. Cohen, and J. A. Kern. 1990. Expression of the neu gene-encoded protein ( $\mathrm{P} 185^{\text {neu }}$ ) in human non-small cell carcinomas of the lung. Cancer Res. 50:421-425.

10. Shi, Daren, Gongping He, Shilong Cao, Wensheng Pan, Hua-Zhong Zhang, Dihua Yu, and Mien-Chie Hung. 1992. Overexpression of the c-erbB-2/ neu-encoded p185 protein in primary lung cancer. Mol. Carcinog. 213-218.

11. Schneider, P. M., M.-C. Hung, S. M. Chiocca, J. Manning, X. Zhao, K Fang, and J. A. Roth. 1989. Differential expression of the c-erbB-2 gene in human small cell and non-small cell lung cancer. Cancer Res. 49:4968-4971.

12. Tateishi, M., T. Ishida, T. Mitsudomi, S. Kaneko, and K. Sugimachi 1991. Prognostic value of c-erbB-2 protein expression in human lung adenocarcinoma and squamous cell carcinoma. Eur. J. Cancer. 27:1372-1375.

13. Paakko, P., K. Nuorva, D. Kamel, and Y. Soini. 1992. Evidence by in situ hybridization that c-erbB-2 proto-oncogene expression is a marker of malignancy and is expressed in lung adenocarcinomas. Am. J. Respir. Cell Mol. Biol. 7:325334

14. Kern, J. A., D. A. Schwartz, J. E. Nordberg, D. B. Weiner, M. I. Greene, L. Torney, and R. A. Robinson. 1990. p1 $85^{\text {neu }}$ expression in human lung adenocarcinomas predicts shortened survival. Cancer Res. 50:5184-5191.

15. Iman, D. S., and C. C. Harris. 1991. Oncogenes and tumor suppressor genes in human lung carcinogenesis. Crit. Rev. Oncog. 2(2):161-171.

16. Cline, M. J., and H. Battifora. 1987. Abnormalities of proto-oncogenes in non-small cell lung cancer: Correlations with tumor type and clinical characteristics. Cancer. 60:2669-2674.

17. Hajj, C., R. Akoum, E. Bradley, F. Paquin, and J. Ayoub. 1990. DNA alterations at proto-oncogene loci and their clinical significance in operable nonsmall cell lung cancer. Cancer. 66:733-739.

18. Viallet, J., and J. D. Minna. 1990. Dominant oncogenes and tumor suppressor genes in the pathogenesis of lung cancer. Am. J. Respir. Cell Mol. Biol. 2:225-232.

19. Takahashi, T., Y. Obata, Y. Sekido, T. Hida, R. Ueda, H. Watanabe, Y. Ariyoshi, T. Sugiura, and T. Takahashi. 1989. Expression and amplification of $m y c$ gene family in small cell lung cancer and its relation to biological characteristics. Cancer Res. 49:2683-2688.

20. Harbour, J. W., S.-L. Lai, J. Whang-Peng, A. F. Gazdar, J. D. Minna, and F. J. Kaye. 1988. Abnormalities in structure and expression of the human retinoblastoma gene in SCLC. Science (Wash. DC). 241:353-357.

21. Yokota, J., T. Akiyama, Y.-K. T. Fung, W. F. Benedict, Y. Namba, M. Hanaoka, M. Wada, T. Terasaki, Y. Shimosato, T. Sugimura, and M. Terada. 1988. Altered expression of the retinoblastoma (RB) gene in small-cell carcinoma of the lung. Oncogene. 3:471-475.

22. Herskowitz, I. 1987. Functional inactivation of genes by dominant negative mutation. Nature (Lond.). 329:219-222.

23. Takahashi, T., M. M. Nau, I. Chiba, M. J. Birrer, R. K. Rosenberg, M. Vinocour, M. Levitt, H. Pass, A. F. Gazdar, and J. D. Minna. 1989. p53: A frequent target for genetic abnormalities in lung cancer. Science (Wash. DC). 246:491-499.

24. Xu, H.-J., S.-X. Hu, P. T. Cagle, G. E. Moore, and W. F. Benedict. 1991. Absence of retinoblastoma protein expression in primary non-small cell lung carcinomas. Cancer Res. 51:2735-2739.

25. Zech, L., J. Bergh, and K. Nilsson. 1985. Karyotypic characterization of established cell lines and short-term cultures of human lung cancers. Cancer Genet. Cytogenet. 15:335-347.

26. Horio, Y., T. Takahashi, T. Kuroishi, K. Hibi, M. Suyama, T. Niimi, K. Shimokata, K. Yamakawa, Y. Nakamura, R. Ueda, and T. Takahashi. 1993. Prognostic significance of $p 53$ mutations and $3 p$ deletions in primary resected non-small cell lung cancer. Cancer Res. 53:1-4.

27. Miyamoto, H., M. Harada, H. Isobe, H. D. Akita, H. Haneda, E. Yamaguchi, N. Kuzumaki, and Y. Kawakami. 1991. Prognostic value of nuclear DNA content and expression of the ras oncogene product in lung cancer. Cancer Res. 51:6346-6350.

28. World Health Organization. 1981. International histological classification of tumors, No. 1. In Histological Typing of Large Tumors. 2nd ed. Geneva. 24-26.

29. Kern, J. A., R. A. Robinson, A. Gazdar, L. Torney, and D. B. Weiner. 1992. Mechanisms of $P 185^{\text {HER2 }}$ expression in human non-small cell lung cancer cell lines. Am. J. Respir. Cell Mol. Biol. 6:359-363.

30. Verlaan-deVries, M., M. E. Bogaard, H. van den Elst, J. H. vanBoom, A. J. van der Eb, and J. L. Bos. 1986. A dot-blot screening procedure for mutated ras oncogenes using synthetic oligodeoxynucleotides. Gene. 50:313-320.

31. Slebos, R. J. C., L. Boerrigter, S. G. Evers, P. Wisman, W. J. Mooi, and S. Rodenhuis. 1992. A rapid and simple procedure for the routine detection of ras point mutations in formalin-fixed, paraffin-embedded tissues. Diagn. Mol. Pathol. 1(2):136-141.

32. Kaplan, E. L., and P. Meir. 1958. Nonparametric estimation from incomplete observations. J. Am. Stat. Assoc. 53:457-481.

33. Cox, D. P., and D. Oakes. 1984. Analysis of Survival Data. Chapman and Hall, New York. 201 pp.

34. Sklar, M. D. 1988. The ras oncogenes increase the intrinsic resistance of NIH 3T3 cells to ionizing radiation. Science (Wash. DC). 239:645-647.

35. Sklar, M. D. 1988. Increased resistance to cis-diamminedichloroplatinum (II) in NIH 3T3 cells transformed by ras oncogenes. Cancer Res. 48:793-797. 